\title{
Revisiting Rhetoric in the Era of Politicized Media and Mediatized Politics: Interview with Emeritus Professor Herbert W. Simons of Temple University
}

Jefferson Lyndon D. Ragragio

We revisit a phenomenon in order to reconfigure its applicability to present day. Now more than ever we revisit the phenomenon of rhetoric to re-examine its value in the nexus between media and politics. We aim to situate the role of rhetoric when media is politicized and politics becomes mediatized.

Rhetoric in its quintessential notion centers on persuasion (Burke, 1969; Simons, 1989). It aims to modify beliefs, values, or attitudes. Rhetoric manifests in individual and organizational practices (Simons, 1976, 1989). This very same disposition applies to the media because the media constructs reality and shapes the public mind (see for example Hall, 1996; O'Shaughnessy, 1999).

To shed light on our understanding of rhetoric we ask Herbert W. Simons, Emeritus Professor of Communication at Temple University, Philadelphia, Pennsylvania, USA, about the logic of rhetoric in times when the likes of President-elect Donald J. Trump occupy the headlines. His scholarship has been widely cited in the disciplines of rhetoric and political persuasion, and social movements.

Jefferson Lyndon D. Ragragio (JLDR): What led you to rhetoric and political persuasion? Can you tell us something about the breakthroughs or what we sometimes call the defining moments in your scholarship that led you to this discipline? 
Herbert W. Simmons (HWS): I came to rhetoric quite by accident. As an undergraduate major in psychology I studied persuasion from a behavioral, social psychological perspective and was only dimly aware of a field of study called rhetoric.

I debated in college and did passably well at debate tournaments, but I never became a tournament enthusiast. My family's compulsion to argue loudly and angrily as in a Woody Allen movie soured me on competitive debate. I preferred public discussion, which I did at University of Vermont, and going with other undergraduates to small towns where [we] got people talking about issues of concern to their communities. Years later I ran "discourse analysis" conferences for colleagues in the U.S. and Temple Issues Forum (TIF) on issues of common concern to the Temple University community. This is a continuing interest for me and I hope to renew TIF at Temple University and possibly organize TIF-like entities abroad under Fulbright auspices.

In graduate school at Purdue University, rhetoric and public address courses did not interest me, and neither did organizational communication, which I came to Purdue to study, mistakenly. But in the late sixties, when I became an activist, organizational communication suddenly took on new meaning as a way of understanding social movements. Resource management theory, drawn from organizational studies in sociology, was then the rage. My first writings on social movements drew on organizational communication, sociology, and my own experience as an activist.

JLDR: You have been with Temple University since 1960. Back in the day, how will you describe the interest or disinterest in rhetoric? How much of communication scholarship in the sixties was attributed to the study of rhetoric?

HWS: I probably would never have come to rhetoric-as-discipline were it not for Kenneth Burke. One of my Discourse Analysis conferences led to a co-edited book The Legacy of Kenneth Burke (University of Wisconsin Press). Several of my edited books were conference products, including The Rhetorical Turn: Invention and Persuasion in the Conduct of Inquiry (University of Chicago Press, 1990) and Rhetoric in the Human Sciences (Sage Publications, 1989).

By the eighties, rhetoric's accepted scope had greatly expanded to include the sciences and inquiry more generally. I co-edited the book After Postmodernism: Reconstructing Ideology Critique (Sage Publications, 1995) with my good friend Michael Billig. 
I would recommend Burke's A Rhetoric of Motives (University of California Press, 1969) for his ironic take on "Traditional Principles of Rhetoric" and much more. At a conference I attended on Edwin Black \& Lloyd F. Bitzer's The Prospect of Rhetoric a colleague recommended Burke's writings and urged that I read him as a comedian of sorts. Feel free to also look at Burke's Collected Poems, 1915-1967 (University of California Press, 1968).

Other relevant materials then included Roberts and Good's The Recovery of Rhetoric: The Recovery of Rhetoric: Persuasive Discourse and Disciplinarity in the Human Sciences (The University of Virginia Press, 1993), McCloskey's Rhetoric of Economics (The University of Iowa, 1983) and Michael Billig, Susan Condor, Derek Edwards, and Alan Radley's Ideological Dilemmas: A Social Psychology of Everyday Thinking (Sage Publications, 1988). There's much more I could share with you and the class e.g. Smith's Belief E Resistance (Harvard University Press, 1997), Billig's books on rhetoric, George Lakoff and Mark Johnson's Metaphors We Live By (University of Chicago Press, 1980). That's a start.

JLDR: In the book Rhetoric in the Human Sciences (Sage Publications), which you edited in 1989, you articulated the rhetorical turn/return that paved the way for the reconstitution of the human sciences in rhetorical terms. Can you elaborate on what you mean by rhetorical turn?

HWS: I attended many conferences in the eighties and nineties, and organized others. One of them led to Nelson, Megill, and McCloskey's Rhetoric of the Human Sciences (University of Wisconsin Press, 1990). Philosopher Richard Rorty observed that disciplinary histories were marked by turns like the linguistic and the rhetorical. My complete interpretation can be found in The Rhetorical Turn: Invention and Persuasion in the Conduct of Inquiry (University of Chicago Press, 1990).

At that time there were a lot of competing efforts to establish the new intellectual movement: sociology of scientific knowledge, history of science, and rhetorical turn. All of them were greatly influenced by Thomas Kuhn's The Structure of Scientific Revolutions (University of Chicago Press, 1962) where he introduced the concept and history of paradigm clashes and the conversion experience via persuasion.

JLDR: Within the academe rhetoric is still dominated by the West. This is evident in journals like Quarterly Journal of Speech published by Routledge on behalf of the National Communication Association, and Rhetoric Society Quarterly and Rhetoric Review by Taylor \& Francis. 
How can we address this seeming imbalance, at least in terms of WestEast scholarship?

HWS: Excellent question on rhetorical studies in the West compared with the East, especially China. Your younger generation of $\mathrm{PhD}$ scholars can correct the imbalance. China's politics offers a rich storehouse on which to draw. There is a lot that can be done with China and old-style versus new social movements, including social media.

JLDR: In your essay "Communication and Social Change: The Technoculture, the Counterculture, and the Futureculture" (1975), you discussed how technology could affect the way we approach our social and cultural development. Can you elaborate?

HWS: For context, the sixties and seventies were rife with lifestyle experimentation, with the publication of works like The Making of a Counter Culture: Reflections on the Technocratic Society and Its Youthful Opposition (University of California Press, 1969) and The Greening of America (Random House, 1970). I placed the "techno" and "counter" cultures in dialectical opposition and fantasized on possibilities for transformation. You can learn from the Hippie movement; the poetry of Allen Greenberg, Leonard Cohen, and Bob Dylan; the films One Flew Over the Cuckoo's Nest (1975, dir. Miloš Forman), the film The Man in the Gray Funnel Suit (1956, dir. Nunnally Johnson).

JLDR: Do technological-savvy journalists, media strategists-owners, and the devout young media consumers-all part of the "Futureculture"dominate the current global media landscape?

HWS: I think this question of yours calls for more research on the effects of the counter-culture and "new" technologies-like the internet and miniaturized computers - on the transformation of work. I can't answer your question but think they are good ones.

JLDR: In the article "Transitional Rhetoric of Chinese Communist Party Leaders in the Post-Mao Reform Period," which you co-authored with Xing $\mathrm{Lu}$ in 2006, you articulated that societies undergoing political transformations are always "rhetorically problematic." Can you explain the rhetorical problems during political transformations? I suspect that these problems may have occurred as well in countries like Singapore, Ukraine, and the Philippines that underwent or are undergoing political transitions. 
HWS: China's transition has similarities with that of other countries. The Chinese transition from feudalism to socialism and then to a market economy is especially interesting because the ruling elite guarded its official ideology to allow China's government retained control as it liberalized slowly.

Singapore is interesting, as is the mostly nonviolent velvet revolution in Eastern Europe.

Political leaders play interesting language games to manage the transitional process. Deng Xiaoping's socialism infused "God terms" like "harmony" and "ecological balance" with Hu/Wen; Jiang's Three represent and call entrepreneurs to join the Chinese Communist Party; and Ji Ping comments on dreams. All these leaders had to balance Confucian right thinking, Maoist orthodoxy, and modernism.

JLDR: I can sense your passion for U.S. politics. What are your general thoughts about the recent victory of Mr. Donald J. Trump? By winning the United States Electoral College, does he now qualify as a political rhetor based on your standards and parameters?

HWS: I included a case study of both Trump's presidential campaign in my upcoming book. On a positive note I think he broke with the tradition of reading scripted speeches and a reliance on a teleprompter. But I still think he is a misogynist, demagogue, xenophobe, white nationalist, shoot-from-the-hip, ill-informed, presumptive liar indifferent to the truth, as with his accounts of Trump University.

JLDR: A number of global media entities like CNN International hosted a series of pre-elections online polls between Mr. Trump and Mrs. Clinton. While polls predicted Mrs. Clinton's victory, the election proved otherwise. Are we seeing one of Erving Goffman's media framing at work?

HWS: I agree that media framing is important. Paul Krugman's studies noted how little TV news time is devoted to policy issues during campaigns and how ill-informed the American public is on issues. My upcoming book describes American voters' level of rationality, which will become evident with how the citizenry acts against its own vested interest.

JLDR: Do you see some kind of misconception in the way the media use the term "rhetoric" in their reportage?

HWS: I don't think they are misconceptions of "rhetoric" as they are differing conceptions. The term "rhetoric" is amenable to multiple conceptions. It is polysemic. 
JLDR: With the victory of the likes of Mr. Trump who is apparently fond of verbalizing incongruous and sometimes obnoxious phrases, how should the media contextualize his public statements?

HWS: Media institutions have multiple criteria for guiding news reporting, analysis, and commentary including accuracy, balance or evenhandedness, and sound judgment. While these criteria often contradict each other-as in their coverage of Brexit-they must serve as guiding principles in news reporting.

JLDR: What can we expect from your future scholarship and endeavours?

HWS: I have one goal: to finish my book. It's close. Then I may return to directing Temple Issues Forum at Temple University.

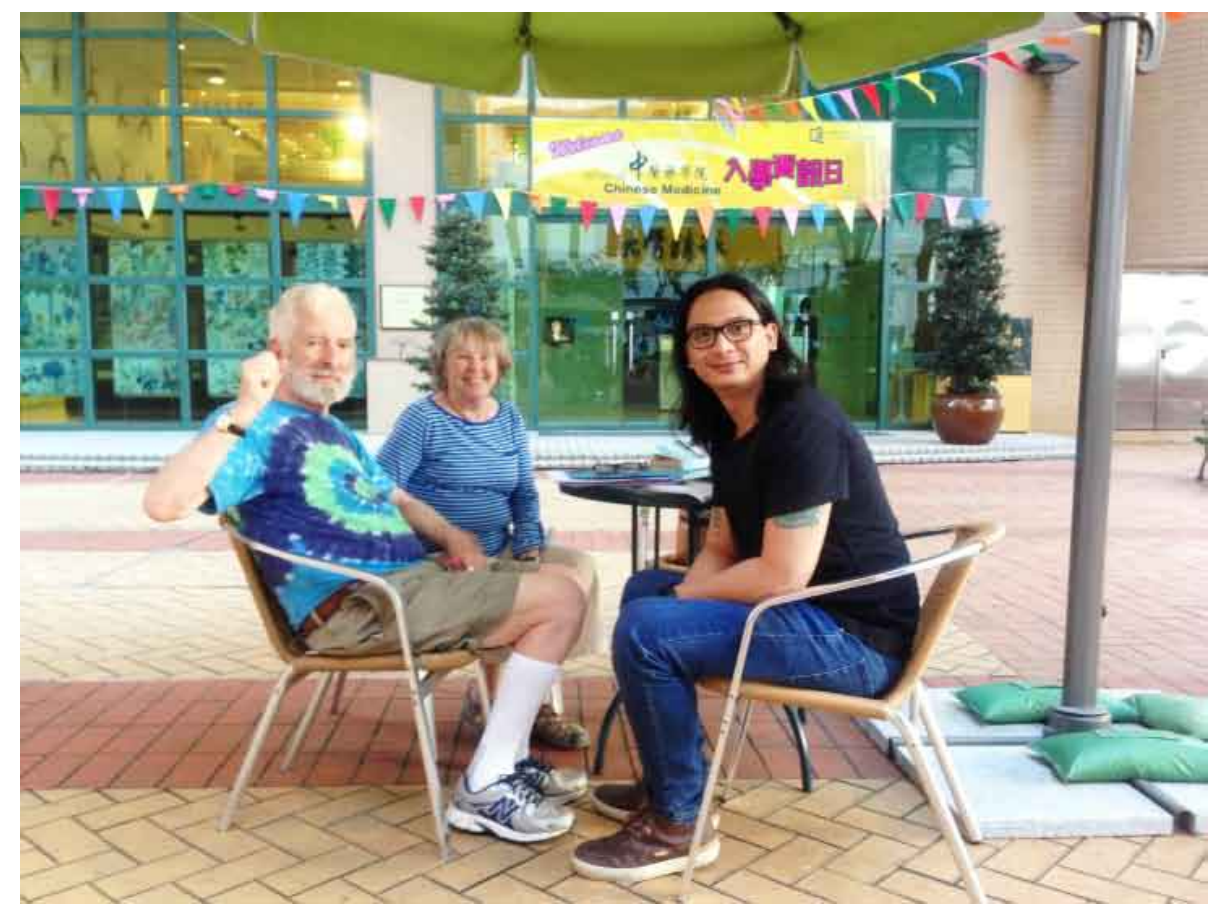

Conversation about U.S. elections, the media, Hong Kong and the Philippines in front of Hong Kong Baptist University's School of Chinese Medicine on 13 October 2016. (L-R: Emeritus Professor Simons with his good wife Gayle and the Author) 


\section{References:}

Burke, K. (1969). A rhetoric of motives. Los Angeles, California: University of California Press.

Hall, S. (1996). Introduction:Who needs "identity"? In S. Hall \& P. Du Gay (Eds.), Questions of cultural identity (pp. 1-17). London:SAGE.

Lu, X., \& Simons, H. W. (2006). Transitional rhetoric of Chinese Communist Party leaders in the postMao reform period: Dilemmas and strategies. Quarterly Journal of Speech, 92(3), 262-286. doi: 10.1080/00335630600938674

O'Shaughnessy, M. (1999). Media and society: An introduction. South Melbourne, Vic.: Oxford University Press.

Simons, H.W. (1975). Communication and social change:The techno-culture, the counterculture, and the futureculture. Vital Speeches of the Day, 42, 243-246.

Simons, H.W. (1976). Persuasion: Understanding, practice, and analysis. Reading, Mass.: Addison-Wesley. Simons, H.W. (1989). Introduction. In H.W. Simons (Ed.), Rhetoric in the Human Sciences (pp. 1-9). London: SAGE

JEFFERSON LYNDON D. RAGRAGIO is a PhD Fellow in Journalism in the School of Communication at Hong Kong Baptist University. He writes on media and politics, press freedom and political movements (corresponding author: jeffragragio@gmail.com). (Corresponding author:jeffragragio@gmail.com) 
